\title{
Den medisinske selvmorderen i individualismens tid
}

\author{
Av Lars Johan Materstvedt
}

\section{SAMMENDRAG}

Artikkelen starter med en drøfting av selvmordets rasjonalitet sett fra en filosofisk synsvinkel. Deretter forklares og defineres termene «eutanasi» og «legeassistert selvmord», som begge fortolkes moralsk som former for kontrollerte, medikaliserte selvmord. Det gis deretter en beskrivelse av hvor normalisert begge deler har blitt i BeNeLux-landene, og at dette kan leses som uttrykk for en individualistisk kultur der kontroll med egen død er blitt stadig viktigere. Artikkelen beskriver også hvordan praksisen med assistert selvmord i Sveits er spesiell ved at den ikke involverer helsepersonell i særlig grad. Dernest beskrives norsk forskning på kreftpasienters forhold til eutanasi og legeassistert selvmord, samt at pasienters ønske om disse typene unaturlig død kan være svært komplekse. Til slutt problematiseres forestillingen om at vi vet vår eget beste, og det antydes at vi er mindre rasjonelle enn vi har for vane å tro.

The present article takes as its point of departure a discussion of the rationality of suicide from a philosophical point of view. It goes on to explain and define the terms "euthanasia" and "physician-assisted suicide", which are both given a moral interpretation as forms of controlled, medicalised suicide. Subsequently, a description is offered of how normalised both practices have become in the BeNeLux countries, and that this phenomenon may be seen as an expression of an individualistic culture in which control of one's own death has gained increased importance over the years. The article also delineates in what way the practice of assisted suicide in Switzerland is particular in that health care personnel are involved in a quite limited fashion. There follows a presentation of research carried out in Norway directed at cancer patients regarding their views of, and attitudes towards, euthanasia and physician-assisted suicide. It is also pointed out that a wish for either type of unnatural death can be very complex. The article ends by casting doubt on the idea that we know our own best interests, and it is suggested that we are less rational than we normally see ourselves as.

ER DET NOENSINNE rasjonelt å ta sitt liv? Spør man en filosof, som undertegnede er, kan jeg garantere at vedkommende umiddelbart vil spørre tilbake: «Hva mener du med 'rasjonelt'?» Det finnes en hel skog, for ikke å si flere skoger, av filosofisk litteratur om begrepet. Og det er slett ingen enighet om dets innhold - til tross for at enkelte prøver (hardt) å fange rasionalitetens vesen.

Et eksempel er Harvard-filosofen Robert Nozick (1938-2002), som i 1993 utga en bok med den ambisiøse tittelen The Nature of Rationality. Et annet er den tyske filosofen Karl-Otto Apel (Materstvedt, 1999). I Norge er særlig Ion Elster kjent for sine teorier om rasjonalitet, eksempelvis i Ulysses and the Sirens (1979). Så svaret avhenger helt av hvilken teori man «sokner» til - en teori som selv må begrunnes, ingen liten jobb ...

Men jeg skal ikke plage leserne av Suicidologi med mer utlegning av dette feltet. I stedet skal jeg gå rett på sak, og relatere spørsmålet til en medisinsk kontekst: Finnes det noen lidelser som er av en slik art at det kan være rasjonelt å drepe seg selv? To av de mest sentrale filosofene i den klassiske liberale tradisionen, Thomas Hobbes (1588-1679) og Immanuel Kant (1724-1804), har skrevet mye som er relevant for dette spørsmålet. 


\section{Hobbes: selvmordere er «nuts» - men alltid?}

Hobbes betrakter selvmord som uttrykk for at personen er «nuts» - gal, sprø, sinnssyk. Som han understreker, kan han ikke forstå («conceive») dette på noen annen måte:

I conceive not how any Man can bear Animum felleum, or so much Malice towards himself, as to hurt himself voluntarily, much less to kill himself; for naturally, and necessarily the Intention of every Man aimeth at somewhat, which is good to himself, and tendeth to his preservation: and therefore, methinks, if he kill himself, it is to be presumed that he is not compos mentis, but by some inward torment or Apprehension of somewhat worse than Death, Distracted (Hobbes, 1971, s. 116-17).

En person som dreper seg selv er ikke ved sine fulle fem (compos mentis), og dermed heller ikke (strafferettslig) tilregnelig slik Hobbes ser det. Det er noe annet som driver eller «distraherer» (distract) ham til å begå selvmord, en «indre pine» (inward torment) eller engstelse (apprehension) for at han går i møte en skjebne verre enn døden.

I Hobbes' politiske filosofi er selvoppholdelsesdriften, eller omvendt formulert: dødsfrykten, fundamental for alle våre handlinger, og får oss til sammen å etablere en stat kjennetegnet av det sosiologen Max Weber kalte et «legitimt voldsmonopol» bestående av politi og militærvesen - et apparat som kan beskytte oss alle. En av de mest berømte passasjene i hans hovedverk Leviathan er, i tråd med denne tankegangen, følgende - der han beskriver den statsløse «naturtilstanden»:

In such a condition there is no place for industry; ... no arts; ... no society; and which is worst of all, continual fear, and danger of violent death; and the life of man, solitary, poor, nasty, brutish, and short (Hobbes, 1985, Chapter XIII. Of the Natural Condition of Mankind as Concerning Their Felicity and Misery, s. 186).

Ethvert rasjonelt vesen vil søke å unnslippe dette helvete på jord. Og det er nettopp fordi den rasjonelle ikke har suicidale trekk at han eller hun vil velge å institusjonalisere (etablere) en sterk stat som en trygg «utvei» fra naturtilstanden.

Hobbes' verdensbilde kan beskrives som mekanistisk-deterministisk, påvirket av den vitenskapelige revolusion i renessansen, med store navn som Kepler, Kopernikus, Galilei og Newton. Slik Hobbes ser individet i lys av dette verdensbildet, hefter det en fundamental «mekanisk feil» ved de menneskekropper som bevisst destruerer seg selv - altså begår selvmord. 
Likevel kan vi spørre om det ikke her foreligger en spenning i Hobbes' tenkning. For som vi så, sier han at det nødvendigvis er slik at mennesket sikter mot det som er godt for en selv («necessarily the Intention of every Man aimeth at somewhat, which is good to

Det finnes flere varianter av medikaliserte drap som er frivillige - hva enn man måtte legge $i$ «frivillig» himself»). Sett nå at man er under grufull tortur som har til hensikt å fravriste en statshemmeligheter, og man vet at utgangen på det hele er henrettelse. Dette kan da oppfattes som en skjebne verre enn døden («worse than Death»), i

hvilket tilfelle døden fremstår som et gode. Vil det ikke da være rasjonelt å ta sitt liv jo før jo heller?

Overført til vårt tema, kan man spørre hvilke implikasjoner Hobbes' syn har i konteksten eutanasi og legeassistert selvmord (se definisjoner nedenfor). For i den grad pasienter oppfatter sin lidelse som torturlignende, virker det som om Hobbes vil kunne se på begge deler som rasjonelle handlinger.

\section{Kant: selvmordet er moralsk forkastelig, men forståelig - og unntaksvis rasjonelt?}

Få tenkere har fordømt selvmordet sterkere enn Kant; det er en forbrytelse mot moralen. Likevel uttrykker han forståelse for at noen kan ønske å ta sitt liv. Men selv om noen følelsesmessig kan ønske dette, kan de ikke rasjonelt ville ta sitt liv. I tidenes kanskje mest berømte verk innen etikk, Grundlegung, skriver Kant om disse problemstillingene:

Et menneske er blitt trett av livet på grunn av en rekke lidelser som har hopet seg opp slik at alt virker håplost [Hoffnungslosigkeit]. Men det har fremdeles så meget fornuft i behold at det kan spørre seg selv om det ikke ville være i strid med ens plikt overfor seg selv å ta sitt liv (Kant, 1983, Ak. 422, s. 40).

Den som tar sitt eget liv mot en slik bakgrunn (i en slik situasion), handler imidlertid utifra «egenkjærlighet [Selbstliebe] ... dette egoistiske prinsipp [som] strider ... fullstendig mot det øverste prinsipp for all plikt» (Kant, 1983, Ak. 422, s. 40).

Og, fortsetter han,

hva angår begrepet om den nodvendige plikt mot seg selv, [så vil] den person som tenker på selvmord sporre seg hvorvidt hans handling er forenlig med idéen om menneskeheten som et formål i seg selv [als Zweks an sich selbst]? Hvis han for å komme unna en plagsom tilstand odelegger seg selv, så benytter han seg av en person bare som et middel til å opprettholde en tålelig tilstand til livets slutt (Kant, 1983, Ak. 429, s. 46-7).
Som om ikke det var nok, i det senere verket Tugendlehre skriver han: ${ }^{1}$

Selvmordet er en forbrytelse [Verbrechen (Mord)]. Det kan også betraktes som et brudd på ens plikt [Pflicht] overfor andre mennesker (ektefeller, foreldre overfor barn, ...) ... (Kant, 1990, Des ersten Hauptstücks erster Artikel. Von der Selbstentleibung, § 6, s. 59).

Ikke desto mindre åpner Kant nettopp i Tugendlehre for at selvmord i ekstreme situasjoner kan være på sin plass - riktignok uten at han konkluderer. I stedet lar han temaet bli hengende i luften, ved kun å spørre om personen i dette tilfellet begikk en moralsk feil:

En mann som ble bitt av en gal hund kiente allerede at virkningen rabiesangst var i ferd med å innhente ham. I et brev han etterlot seg, skrev han at han aldri hadde hort at noen hadde blitt kurert for denne sykdommen, og han tok derfor sitt liv for å unngå å skade andre mennesker $i$ sin galskap (som han allerede kjente komme). Sporsmålet er om han dermed handlet galt (Kant, 1990, Des ersten Hauptstücks erster Artikel. Von der Selbstentleibung, § 6, Kasuistische Fragen, s. 61).

Men her er det altså ikke hensynet til en selv som er argumentet, men hensynet til andre: Et eventuelt selvmord vil ikke da være egoistisk, men altruistisk (uegennyttig) for å beskytte andre mot å bli skadet - kanskje til og med fatalt. Altså et mål-rasjonelt selvmord.

Jeg har annetsteds argumentert for at selv om Kant mener selvmordet er moralsk «forbudt», ville han neppe støttet et juridisk forbud - og muligens akseptert lover som tillater eutanasi og legeassistert selvmord (Materstvedt, 2015a), som jeg nå skal definere.

\section{Varianter av medikaliserte drap}

Det finnes flere varianter av medikaliserte drap som er frivillige - hva enn man måtte legge i «frivillig». Først og fremst har man følgende to varianter, som også er mest utbredt i praksis (Materstvedt \& Kaasa, 2016, s. 85):

Eutanasi (E): En leges intenderte (tilsiktede) drap på en person ved å injisere medikamenter, på personens frivillige og kompetente forespørsel. Forst gis sovemedisin som injeksion eller infusion for at pasienten skal falle $i$ koma, deretter muskelavslappende medisin med respirasjonsstopp som resultat. Dette medforer hiertestans, og pasienten dor i lopet av sekunder eller minutter.

Legeassistert selvmord (LAS): En leges intenderte hielp til en person i dennes selvmord, ved å skaffe til veie medikamenter som personen kan innta selv, på personens frivillige og kompetente foresporsel. Pasienten svelger en overdose sovemedisin som forårsaker bevisstloshet og respirasionsstopp, hvorpå hiertet slutter å slå. Alternativt 
kan det brukes selvmordsmaskin, der legen har rigget til en infusion, men som utloses av pasienten.

Også i artikkelen «Fra aktiv og passiv dødshielp til eutanasi og behandlingsbegrensning» giør undertegnede og lege, professor i medisinsk etikk Reidun Førde, nærmere rede for denne begrepsbruken og disse distinksionene (Materstvedt \& Førde, 2011). Jeg vil også vise til min artikkel «Legeforeningens uklarhet om 'aktiv dødshjelp’» (Materstvedt, 2016a). En mer dyptpløyende analyse finnes i Materstvedt \& Magelssen (2016): «Medical murder in Belgium and the Netherlands».

Eutanasi er bare nedfelt i lov i BeNeLux-landene og i Canada, mens assistert selvmord er lovregulert både i disse landene og i Sveits og Tyskland, samt i flere delstater i USA; det vises til tabell 5.3 Steder der assistert død er legalt, i Materstvedt \& Kaasa (2016, s. 91).

I dette kapitlet påpeker vi at Canada er unikt ettersom også sykepleiere der kan utføre eutanasi. Det innebærer at definisionen av E ovenfor trenger følgende «justering»: «En leges eller sykepleiers intenderte ...». Hva gielder LAS, kan jo sykepleiere per definisjon ikke utføre dette, men de tillates i Canada å utføre AS (assistert selvmord), noe som også er unikt (Canada. Lov om eutanasi og assistert selvmord, 2016).

Filosofen Thomas Pogge (2003) hevder at E og LAS moralsk sett er likestilte:

Unlike physician-assisted suicide, euthanasia requires that the physician intends the patient's death. This is not a substantial moral difference when the death is, in both cases, triggered by the patient's own voluntary and competent request. Morally, the event is then suicide assisted by another. The extent to which the patient can physically co-operate makes no moral difference.

Altså begår man, moralsk sett, selvmord både ved $\mathrm{E}$ og LAS (og AS). I denne artikkelen har jeg valgt å legge en slik forståelse til grunn når jeg heretter snakker om «den medisinske selvmorderen»: Pasienten begår selvmord også når han eller hun mottar en leges (eller sykepleiers) dødelige injeksjoner "på bestilling», ikke bare når vedkommende selv svelger en overdose sovemedisin (et barbiturat) som en lege (eller sykepleier) har skaffet til veie.

\section{Det kontrollerte medisinske selvmord}

De aller fleste som blir gienstand for E eller LAS er pasienter med avansert kreft. De finner det således «rasjonelt» å sette strek på unaturlig vis, ikke ved å la naturen gå sin gang slik at de dør av sykdommen.

Men det betyr ikke nødvendig at pasientene er såkalt terminalt syke - et begrep som ikke er klart definert hverken klinisk eller juridisk (Materstvedt \& Syse, 2006). Det er snarere ofte tilfellet at pasienten ikke er i noe som meningsfullt kan kalles «terminalfasen», og vedkommende er gierne relativt oppegående. Et illus- trativt eksempel er den tidligere, landskjente belgiske atleten Emiel Pauwels på 95 år, som fikk diagnosen magekreft. Pauwels holdt avskjedsfest hjemme med en rekke venner og bekjente til stede, og skålte med vin før han dagen etter lot legen ta livet av seg ved eutanasi (Brandeggen, 2014).

Slik orkestrering av eget selvmord har blitt nokså normalt i Nederland og Belgia. Det er nærliggende å tolke dette som uttrykk for en «langt fremskreden» individualistisk kultur, en tematikk som forskningsmessig ligger innenfor kompetansefeltet til kultursosiologer og historikere. Sammen med den sveitsiske legen og bioetikeren Georg Bosshard (www.georgbosshard. ch) omtaler jeg i The SAGE Handbook of Health Care Ethics (2011, s. 202) denne påfallende individualismen slik: «dying not as something that just happens, but something that you do yourself». I den forbindelse giengir vi følgende historie, som forekommer i en bok av den amerikanske bioetikeren Margaret Battin: ${ }^{2}$

To gamle seilerkompiser, hollendere, planlegger å seile $i$ Nordsjøen sammen en gang ut på hosten. De snakker om mulige datoer. "Hva med 21. juli», spør Willem. "Da er siøen rolig, det er fullmåne og dessuten en musikkfestival langs danskekysten». "Høres bra ut», sier Joost. «Men jeg kan ikke være borte da. Den 21. er datoen for min fars dod». «Åh, jeg beklager», svarer Willem. «leg visste at din far var svært syk, med kreft. Men jeg var ikke klar over at han var dod». "Det er han da heller ikke», svarer Joost. «Den 21. er dagen han skal do. Han har bestemt seg, og bestemt datoen, og vi vil alle være sammen når det skier».

Annetsteds har jeg påpekt at det synes å være en «sosial lov» at legalisering av en medisinsk praksis fører til institusjonalisering av praksisen (i helsevesenet), hvorpå man blir vitne til dens normalisering (Materstvedt, 2013).

Hvor innarbeidet og normalt det medisinske selvmordet har blitt i BeNeLux-landene illustreres også av at flere pasientgrupper nå mottar dette «helsetilbudet». Mange kaller dette en utglidning - jf. det kjente uttrykket «slippery slope» - men det kan jeg ikke si meg enig i. For rutsjebanen var såpeglatt allerede $\mathrm{i}$ utgangspunktet. Både loven i Nederland og Belgia har to basale hovedkrav: Pasientens lidelse må være Rutsjebanen var såpeglatt allerede i utgangspunktet «utålelig»/«uutholdelig», og det må «ikke være utsikter til bedring» (Nederland. Lov om eutanasi, 2002; Belgia. Lov om eutanasi, 2002). Med så løse kriterier var det duket for inkludering av en rekke lidelsestyper; tolkningsrommet er meget stort.

Og her er vi ved et vesentlig punkt: Referansen er ikke primært til «sykdom», men nettopp «lidelse». Dette er godt beskrevet i den belgiske loven, som er svært lik 
den nederlandske, men har en mer detaljert utforming. Loven krever at pasienten må befinne seg

in a medically futile condition of constant and unbearable physical or mental suffering that can not be alleviated, resulting from a serious and incurable disorder caused by illness or accident (Belgia. Lov om eutanasi, 2002. Chapter II, sect. 3, §1).

Et eksempel på hva dette vil kunne innebære, er følgende: I 2014 kiørte langrennsstiernen Petter Northug i beruset tilstand, og krasjet i en rundkjøring på Byåsen i Trondheim. Bilen ble totalvrak, men Northug kom fra det

Et sentralt sporsmål er om vi vil se flere slike pasienter med tiden uten alvorlige skader. Sett nå at han i stedet hadde blitt permanent lam fra livet og ned, og at Norge hadde en eutanasilov lik den belgiske. Da kunne han fått eutanasi om han fant det uutholdelig å leve som lam og aldri mer kunne gå på ski (jf. lovens «unbearable mental suffering»). Det er lett å se hvorfor: Tilstanden er dertil uten utsikter til bedring. Ergo ville hovedkravene vært oppfylt.

I artikkelen «The Death Treatment» (2015) gir journalisten Rachel Aviv et meget interessant bilde av utviklingen i Belgia - et bilde som dessuten er helt korrekt både når det gielder lovgiving, begrepsbruk og praksis i landet, noe som er meget sjelden vare $\mathrm{i}$ medieartikler. Én av hennes observasjoner er som følger:

Although most of the Belgian patients had cancer, people have also been euthanized because they had autism, anorexia, borderline personality disorder, chronic-fatigue syndrome, partial paralysis, blindness coupled with deafness, and manic depression.

Den kjente belgiske legen Wim Distelmans eutaniserte (det er blitt et verb) tvillinger som sa de «ikke hadde noe å leve for» fordi de var døve og i ferd med å bli blinde, og ikke ville på institusjon (Waterfield, 2013a). Samme lege ga eutanasi til en mann som onsket å dø etter en mislykket kjønnsskifteoperasjon (Waterfield, 2013b).

I Nederland er «siste nytt» at også en uhelbredelig alkoholiker har fått utført eutanasi (Cook, 2016).

\section{Den ultimate kontrollfrik?}

Den polsk-nederlandske legen Ben Zylicz (www.drbenzylicz.org), som tidligere arbeidet ved et hospice i Nederland, skrev for nærmere 20 år siden om en type pasienter han kaller «control freaks» og som han møtte som lege ved denne institusjonen (Zylicz, 1998). De var ikke mange, knapt et par stykker i året, men det virket ikke som om noen form for palliativ behandling og støtte «bet på dem»: Selv om de ble gitt optimal lindring, ville de likevel ha eutanasi - deres bevissthet var nærmest fiksert på dette.
Et sentralt spørsmål er om vi vil se flere slike pasienter med tiden. Det er imidlertid mye som tyder på dét, når vi tar utviklingen i betraktning: Individualismen og kontrollaspektet har blitt mer fremtredende.

\section{Av-medikalisering av selvmord?}

Sveits har ingen egen AS-lov. Men sveitsisk straffelov åpner for legfolks deltakelse dersom deres assistanse er «uegennyttig». (Eutanasi er derimot forbudt i straffeloven.) Sveits har lenge hatt en «selvmordsturisme»: Pasienter fra andre land drar dit for å begå selvmord med medikamenter (Richards, 2016), også norske pasienter (Materstvedt, 2015b).

En lege må undersøke pasienten og skrive ut resept på selvmordsmedisiner, men deltar normalt ikke ut over det. Det vanlige er at pasienten deretter overtas av frivillige organisasioner som Dignitas (www.dignitas.ch) og Exit (www.exit.ch), som assisterer ved pasientens selvmord når denne tar dødbringende medikamenter. Hver enkelt organisasjon har egne kriterier for hvilke lidelser som kvalifiserer for assistanse (Materstvedt \& Bosshard, 2015).

Sett fra et legeperspektiv er derfor distansen til den medisinske selvmorderen relativt stor - noe mange leger setter pris på (Materstvedt \& Bosshard, 2015). Den sveitsiske legeforeningen har også et distansert forhold til praksisen, ettersom dens syn er at det bryter med legeetikken å gi slik assistanse. Likevel innebærer deres posisjon at legene står fritt til å delta utifra sin samvittighet. Oppsummert kunne vi derfor si at det medisinske selvmord, paradoksalt nok, i betydelig grad er av-medikalisert i Sveits ettersom praksisen holdes på armlengdes avstand av legene.

Det er for tiden et sterkt press fra nøkkelpersoner og -organisasjoner i Nederland som prøver, giennom lovforslag og på andre måter, å fravriste legene deres eutanasi-monopol (Kimsma, 2015). I Materstvedt (2016b) peker jeg på at i tilfeller av livstrøtthet («suffering from life») skulle det ikke engang være nødvendig at en lege undersøker pasienten først; det synes å holde med en filosof som er spesialist på eksistensialisme. Interessant i denne forbindelse er at $26 \%$ av legene i en nylig nederlandsk vitenskapelig undersøkelse mener at livstrøtthet, uten ledsagende alvorlig «utsiktsløs» somatisk eller psykiatrisk sykdom, burde kvalifisere for dødssprøyten (Raijmakers et al., 2015). Men da blir spørsmålet: Hvorfor involvere helsepersonell?

\section{Norske kreftpasienter om E og LAS}

De fleste pasienter som får E eller LAS de steder dette er lovlig er pasienter med avansert kreft. I BeNeLuxlandene er det imidlertid ikke giort forskning direkte på disse pasientene når det gielder deres syn på E og LAS - i stedet er de store studiene av E og LAS i eksempelvis Nederland, utført i årene 1990, 1995, 2001, 2005 og 2010, utelukkende rettet mot leger (Onwuteaka-Philipsen et al., 2012). 


\section{Onsket om å dø ... representerer mer en mestringsstrategi enn et reelt onske}

Men det er giort slik pasientrettet forskning i Norge. Undertegnede ledet, som postdoc-stipendiat i Kreftforeningen (https://kreftforeningen.no), et forskningsprosjekt om holdninger til, og ønsker om, E og LAS hos kreftpasienter med kort forventet levetid. 18 pasienter (8 kvinner og 10 menn) ble intervjuet innenfor en ramme på 45 minutter. Samtlige hadde en antatt levetid på under 9 måneder, og var mellom 38 og 83 år gamle. Pasientene var inneliggende på Seksjon lindrende behandling (SLB), Kreftklinikken, St. Olavs Hospital i Trondheim (https://stolav.no/avdelinger/kreftklinikken/palliasion).

Resultatene ble publisert i tidsskriftet Palliative Medicine (Johansen et al., 2005). Vi utarbeidet et semistrukturert («halvåpent») intervju om tematikken. Det besto av åtte hovedtema, med en rekke underpunkt for hvert av disse. Funnene var interessante fordi pasientenes respons vitnet om både ambivalens og fluktuasjon. Pasienter svarte «både ja og nei» til E og LAS, og én pasient endret til og med syn i løpet av interviuet.

Ønsket om å dø tolket vi, med støtte i psykologisk teori, som en «siste utvei»-tenkning, og at ønsket representerer mer en mestringsstrategi enn et reelt ønske.

Et hovedfunn er skillet mellom «onske» og «forespørsel». Førstnevnte er kjennetegnet ved å være hypotetisk og rettet mot fremtiden, mens sistnevntes «bumerke» er at den er et konkret her-og-nå-fenomen. Vi konkluderte således slik: «A wish for euthanasia/PAS [Physician-Assisted Suicide] may be something completely different from a request for it.»

Hva gielder mulige kliniske konsekvenser i forbindelse med skillet ønske/forespørsel, skriver vi:

The obvious and most dangerous scenario is the doctor who responds to patients' wishes for euthanasia/PAS as if they were actual requests. Alternatively, responding to such wishes as merely expressions of depression might lead to inadequate interventions (e.g., with antidepressants) and possibly further reinforce the patients' feelings of hopelessness. The patient may also see such a response in the doctor as a violation of his autonomy - or as a lack of respect for his decision-making capacities.

\section{Ønsket om å fremskynde døden:}

\section{komplekst og multifaktorelt}

Tidlig i 2016 publiserte et bredt, internasionalt ekspertpanel bestående av klinikere og forskere fra Europa og USA - som undertegnede er medlem av - en konsensus-definision som tar høyde for at svært mange faktorer kan spille inn når pasienter onsker å dø ved injeksion (E) eller oralt inntak av dødelige medisiner (LAS og AS). Definisionen er som følger:
The WTHD [Wish To Hasten Death] is a reaction to suffering, in the context of a life-threatening condition, from which the patient can see no way out other than to accelerate his or her death. This wish may be expressed spontaneously or after being asked about it, but it must be distinguished from the acceptance of impending death or from a wish to die naturally, although preferably soon. The WTHD may arise in response to one or more factors, including physical symptoms (either present or foreseen), psychological distress (e.g. depression, hopelessness, fears, etc.), existential suffering (e.g. loss of meaning in life), or social aspects (e.g. feeling that one is a burden).

Artikkelen (Balaguer et al., 2016) er gratis tilgjengelig i Open Access-tidsskriftet PLOS ONE.

\section{Avsluttende merknader}

Kan det medisinske selvmordet være rasionelt? Vi har sett at det i alle fall ikke er et valg på linje med «normale» valg. Om jeg er tørst og ber om et glass vann, er det åpenbart at min forespørsel er rasionell - nærmere bestemt mål-rasjonell; målet er å slukke tørsten. Ingen kan være i tvil om dét. Om jeg forteller en lege at jeg onsker en dødelig injeksion, er det ikke tilsvarende klart at det er døden jeg vil oppnå. Her er det rom for tvil om dette egentlig er mitt mål. For en slik henvendelse kan ha svært mange betydninger, og det kan ligge mye forskjellig bak. De faktorer som får en til å onske seg ut av livet kan være mange - if. WTHD ovenfor - og kan 
hver for seg være behandlbare, eller mulige å lindre i tilstrekkelig grad, bare kompetansen, ressursene og vilien er til stede i helsevesenet.

På et dypere plan reiser fenomenet «den medisinske selvmorderen» et meget komplisert spørsmål: «Kan vi vite vårt eget beste?» Med andre ord: Hvordan kan jeg vite at jeg er «better off dead», som engelskmennene sier.

Jeg har annetsteds utforsket dette grunnleggende spørsmålet i relativt stor detali (Materstvedt, 2015a). Da så jeg meg nødt til å konkludere med at svaret trolig er «nei», ettersom det er særdeles vanskelig å gi mening til forestillingen om at vi er i stand til å vite vårt eget beste; forestillingen later til å være nærmest fiktiv, hos såvel friske som syke. Dét lyder unektelig som «dårlige nyheter» hva gielder vår antatte rasjonalitet.

Levert: 30.11.16 - Revidert: 07.02.17 - Godkjent: 12.02.17

\section{REFERANSEB}

Aviv, R. (2015). The death treatment. When should people with a non-terminal illness be helped to die? Letter from Belgium. The New Yorker, 22.6. www.newyorker.com/magazine/2015/06/22/the-death-treatment

Balaguer, A., Monforte-Royo, C., Porta-Sales, I., Alonso-Babarro, A., Altisent, R., Aradilla-Herrero, A., Bellido-Pérez, M., Breitbart, W., Centeno, C., Cuervo M.A., Deliens, L., Frerich, G., Gastmans, C., Lichtenfeld, S,. Limonero, I.T., Maier, M.A., Materstvedt, L.I., Nabal, M., Rodin, G., Rosenfeld, B., Schroepfer, T., Tomás-Sábado, I., Trelis, I., Villavicencio-Chávez, C., Voltz, R. An international consensus definition of the wish to hasten death and its related factors. (2016). PLOS ONE, Jan 4; 11 (1). http://journals.plos.org/plosone/ article?id=10.1371/journal.pone.0146184

Belgia. Lov om eutanasi. (2002). The Belgian Act on Euthanasia of May 28th. Ethical Perspectives, 9 (2-3), 182-8. www.ethical-perspectives.be/page. $p h$ ? FILE $=e$ _detail $\& I D=33 \& T I D=59$

Bosshard, G., Materstvedt, L.I. (2011). Medical and societal issues in euthanasia and assisted suicide. Chap. 17 i: Chadwick, R., ten Have, H., Meslin, E.M., red. The SAGE Handbook of Health Care Ethics: Core and Emerging Issues. London: SAGE Publications Ltd., s. 205-21.

Brandeggen, T. (2014). Emiel (95) holdt avskjedsfest for han lot legen ta hans liv. TV 2, 14.1. www.tv2.no/2014/01/14/nyheter/aktiv-dodshielp/belgia/ utenriks/5220819

Canada. Lov om eutanasi og assistert selvmord. (2016). www.parl.gc.ca/ HousePublications/Publication.aspx?DocId $=8384014$

Cook, M. (2016). Netherlands offers euthanasia for alcoholics. BioEdge, 29.11. www.bioedge.org/bioethics/netherlands-offers-euthanasia-foralcoholics $/ 12102$

Hobbes, T. (1985). Leviathan. Macpherson, C.B., red. Harmondsworth: Penguin Classics.

Hobbes, T. (1971). A Dialogue Between a Philosopher and a Student of the Common Laws of England, i Cropsey, I., red. Chicago: University of Chicago Press.

Johansen, S., Holen, I.C., Kaasa, S., Loge, I.H., Materstvedt, L.I. (2005). Attitudes towards, and wishes for, euthanasia in advanced cancer patients at a palliative medicine unit. Palliative Medicine; 19: 454-6o. http://pmi.sagepub. com/content/19/6/454.full.pdf

Kant, I. (1983). Grunnlegging av moralens metafysikk [Grundlegung]. I: Storheim, E., red. Moral, politikk og historie. Et utvalg fra Kants praktiske filosofi. Oslo: Universitetsforlaget.
Kant, I. (1990). Metaphysiche Anfangsgründe der Tugendlehre. Hamburg: Felix Meiner Verlag.

Kimsma, G.K. (2015). Longevity reversed: medicide, suicide and laicide after the Euthanasia Law of 2002. Ethics, Medicine and Public Health; 1: 220-9. www.sciencedirect.com/science/article/pii/S2352552515000596

Materstvedt, L.I. (1999). What philosophers can't do: boundaries of Apel's transcendental-pragmatic philosophy. I: Bøe, S., Molander, B., Strandhagen, B., red. I forste, andre og tredje person. Festskrift til Audun 0 fsti. Trondheim: NTNU, Filosofisk institutts publikasjonsserie; 28: 255-64.

Materstvedt, L.J., Syse, A. (2006). Døendes rettsstilling. Tidsskrift for Den norske lægeforening; 126: 488-9. http://tidsskriftet.no/2006/o2/rett-og-urett/ doendes-rettsstilling

Materstvedt, L.J., Forde, R. (2011). Fra aktiv og passiv dødshielp til eutanasi og behandlingsbegrensning. Tidsskrift for Den norske legeforening; 131: 2138-40. http://tidsskriftet.no/2011/11/kronikk/fra-aktiv-og-passivdodshielp-til-eutanasi-og-behandlingsbegrensning

Materstvedt, L.J. (2013). Palliative care ethics: the problems of combining palliation and assisted dying. Progress in Palliative Care; 3: 158-64. www. tandfonline.com/doi/full/10.1179/1743291X12Y.oooooooo40

Materstvedt, L.J. (2015a). Caring and killing in the clinic: the argument of self-determination. Part III, Ethics, Chapter 12 i: Rehmann-Sutter, C., Gudat, H., Ohnsorge, K., red. The Patient's Wish to Die. Research, Ethics, and Palliative Care. Oxford: Oxford University Press, s. 125-38.

Materstvedt, L.I. (2015b). Livsviktig debatt om 'dødshielp'. Kronikk, Stavanger Aftenblad, 20.3. www.aftenbladet.no/meninger/Livsviktigdebatt-om-dodshielp-3659483.htm

Materstvedt, L.I., Bosshard, G. (2015). Euthanasia and palliative care. Chapter 5.7 i: Cherny, N., Fallon, M., Kaasa, S., Portenoy, R., Currow, D., red. Oxford Textbook of Palliative Medicine, 5. utgave. Oxford: Oxford University Press, s. 314-22.

Materstvedt L.J. (2016a). Legeforeningens uklarhet om 'aktiv dødshielp'. Tidsskrift for Den norske legeforening; 136: 1248-50. http://tidsskriftet. no/2016/o8/medisinsk-etikk/legeforeningens-uklarhet-om-aktiv-dodshjelp

Materstvedt, L.J. (2016b). Dødshielp er aldri 'aktiv' eller 'passiv'. I: Forde, R. Kjelland, M., Stridbeck, U., red. Cand.mag., cand.med., cand.jur., cand.alt Festskrift til Aslak Syse 70 år. Oslo: Gyldendal Juridisk, s. 345-55.

Materstvedt, L.J., Kaasa, S. (2016). Palliasion og eutanasi. Kap. 5 i: Kaasa S, Loge, I.H., red. Palliasion. Nordisk lærebok. 3. utgave. Oslo: Gyldendal Akademisk, s. 83-96.

Materstvedt, L.I., Magelssen, M. (2016). Medical murder in Belgium and the Netherlands. Journal of Medical Ethics; 42: 621-4. http://ime.bmi.com/ content/42/9/621.full

Nederland. Lov om eutanasi. (2002). Termination of Life on Request and Assisted Suicide (Review Procedures) Act. UK Parliament: Select Committee on Assisted Dying for the Terminally Ill Bill, Minutes of Evidence - APPENDIX: www.publications.parliament.uk/pa/ld200405/ldselect/ldasdy/86/4121603.htm

Oksholen, T. (2010). Eutanasi kommer. Universitetsavisa NTNU, 3.9. www. universitetsavisa.no/forskning/article37674.ece?device $=p c$

Onwuteaka-Philipsen, B.D., Brinkman-Stoppelenburg, A., Penning, C., de Jong-Krul, G.I., van Delden, I.I., van der Heide, A. (2012). Trends in end-of-life practices before and after the enactment of the euthanasia law in the Netherlands from 1990 to 2010. A repeated cross-sectional survey. Lancet; 380 : 908-15. www.sciencedirect.com/science/article/pii/So140673612610344

Pogge, T. (2003). From New York City. Palliative Medicine; 17: 119. www. eapcnet.eu/LinkClick.aspx?fileticket $=F--I d V S 49 I Y=\& t a b i d=639$

Raijmakers, N.J., van der Heide, A., Kouwenhoven, P.S., van Thiel, G.I., van Delden, I.I., Rietiens, I.A. (2015). Assistance in dying for older people without a serious medical condition who have a wish to die: a national cross-sectional survey. Journal of Medical Ethics, 41, 145-50. http://ime.bmi.com/ content/41/2/145.long 
Richards, N. (2016). Assisted suicide as a remedy for suffering? The end-of-life preferences of British 'suicide tourists'. Medical Anthropology. Cross-Cultural Studies in Health and Illness. www.tandfonline.com/doi/full/ 10.1080/01459740.2016.1255610

Zylicz, B. (1998). Palliative care: Dutch hospice and euthanasia. I: Thomas ma, D.C., Kimbrough-Kushner, T., Kimsma, G.K., Ciesielski-Carlucci, C., red. Asking to Die. Inside the Dutch Debate about Euthanasia. Dordrecht: Kluwer Academic Publishers, s. 187-203.

Waterfield, B. (2013a). Euthanasia twins 'had nothing to live for'. The Telegraph, 14. januar. www.telegraph.co.uk/news/worldnews/ europe/ belgium/9801251/Euthanasia-twinshad-nothing-to-live-for.html

Waterfield, B. (2013b). Belgian killed by euthanasia after a botched sex change operation. The Telegraph, 1. oktober. www.telegraph.co.uk/news/ worldnews/europe/belgium/10346616/Belgian-killed-by-euthanasia-aftera-botched-sex-change-operation.html

NOTER

1 Dette sitatet fra Tugendlehre $\S 6$, samt det påfolgende fra samme paragraf, er oversatt til norsk av artikkelforfatter LIM. Det finnes ikke norske oversettelser av den aktuelle teksten. Originalen: «Die Selbstentleibung ist ein Verbrechen (Mord). Dieses kann nun zwar auch als Übertretung seiner Pflicht gegen andere Menschen (Eheleute, Eltern gegen Kinder, ...) betrachtet werden; ...» \& «Ein Mann empfand schon die Wasserscheu als Wirkung von dem Biß eines tollen Hundes, und, nachdem er sich darüber so erklärt hatte: er habe noch nie erfahren, daß jemand daran geheilt worden sei, brachte er sich selbst um, damit, wie er in einer hinterlassenen Schrift sagte, er nicht in seiner Hundewut (zu welcher er schon den Anfall fühlte) andere Menschen auch unglücklich machte; es fragt sich, ob er damit unrecht tat.»

2 Sitatet er oversatt fra engelsk til norsk av Tore Oksholen, redaktor av Universitetsavisa ved NTNU, i Oksholen (2010).

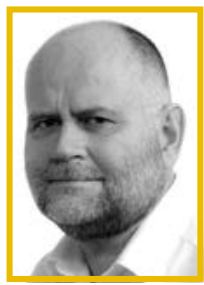

LARS JOHAN MATERSTVEDT (f. 1960) har doktorgrad (dr.art.) i politisk filosofi. Han er professor i filosofi ved Norges teknisk-naturvitenskapelige universitet (NTNU) i Trondheim, og er også tilkjent professorkompetanse i medisinsk etikk. Han er tidligere forsker i Kreftforeningen, og har publisert i bl.a. Lancet Oncology, Oxford Textbook of Palliative Medicine, Journal of Medical Ethics og Palliasjon. Nordisk lærebok. For detaljer, se www.materstvedt.net Noe har våknet. Det svir av seg selv,
verre enn sult og tørst.
Rør ikke ved mitt hierte i kveld. Noe har våknet. Det svir av seg selv,
verre enn sult og tørst.
Rør ikke ved mitt hierte i kveld. Noe har våknet. Det svir av seg selv,
verre enn sult og tørst.
Rør ikke ved mitt hierte i kveld. Bølger av nederlag og savn.
- Trodde jeg det var borte?
Si ikke noe. Nevn ikke navn.
Våren har nettopp giort det. Bølger av nederlag og savn.
- Trodde jeg det var borte?
Si ikke noe. Nevn ikke navn.
Våren har nettopp giort det. Bølger av nederlag og savn.
- Trodde jeg det var borte?
Si ikke noe. Nevn ikke navn.
Våren har nettopp giort det. Bølger av nederlag og savn.
- Trodde jeg det var borte?
Si ikke noe. Nevn ikke navn.
Våren har nettopp giort det.

Rør ikke ved mitt hjerte i dag. Bølger av gammelt nederlag kysser det, hardt og salt. Våren har vært her først.

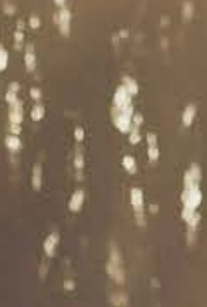

Inger Hagerup Fra diktsamlingen Videre (1945)
Aschehoug forlag 